\title{
BREEDING FOR DEVELOPING NEW INDETERMINATE LINES OF TOMATO (SOLANUM LYCOPERSICUM L.) BY SELECTION
}

\author{
I. M. Mahmoud(1) and Mona R. Khali|(2) \\ (1) Plant Production Department (Vegetable). Fac. Environ. Agric. Sci., Arish Univ., Egypt \\ (2) Horticulture Department, Fac. Agric., Minoufia Univ., Shebin El-Kom, Egypt \\ Received: Mar. 14, 2019 \\ Accepted: Apr. 8, 2019
}

\begin{abstract}
Twenty new lines of indeterminate tomato $\left(F_{6}\right)$ were selected from two $F_{2}$ generations, which exhibited high homogeneity based on estimated CV\% values for plant height, number of leaves/plant, fruit length, fruit diameter and TSS\% content during successive six seasons from 2012/2013 to 2017/2018 at the Experimental Farm, Faculty of Environmental Agricultural Sciences, Arish University, North Sinai under greenhouse conditions. The experimental work was conducted using a Randomized Complete Blocks Design with three replications. A highly significant differences were observed among the selected lines for all studied characters. Lines that showed the most vigorous growth were VL-4-1, VL-4-4, VL-5-1, VL-2-3, VL-7-4 and IR-44-2 and for total yield were VR-6, VR6-40, IRS-43-2, IR-44-1 and IR44-2.The estimated genetic parameters revealed low differences between phenotypic and genotypic coefficient of variations for all studied traits indicating low environmental effects, and the phenotypic selection was effective and suitable for improvement the tomato. High GCV / PCV \% ratios were detected for most studied traits, which suggest that the genetic improvement through selection is possible. The high estimates of heritability in broad sense which ranged from 82.44 to 99.63\% support the possibility of using selection programme. The importance of selection was also supported by the estimated high heritability coupled with high genetic advance as percent of mean for all studied traits.
\end{abstract}

Key words: Tomato, indeterminate lines, homogeneity, genetic variability, heritability, genetic advance, selection.

\section{INTRODUCTION}

Tomato (Solanum lycopersicum L.) is one of the most important vegetable crops in Egypt and worldwide. Their fruits have important nutritive value and health benefits, so it is consumed fresh or in multiple processed forms. It cultivated in open field or under greenhouse conditions. Consequently, there is a need to develop new indeterminate lines or cultivars suitable for cultivation under greenhouse with high yield and fruit quality. This aim could be achieved by breeding programs such selection through the segregating generations.

Breeders hope to find desired plants in the $F_{2}$ and advanced generations. Genetic variability in tomato was studied by many investigators in different countries using various genotypes. Under Egyptian conditions, Kansouh (2002) developed 24 promising lines of tomato from three $F_{2}$ populations by selection, these lines were highly homogenous and suitable for cultivation at Middle Delta Region. In India, Sharanappa and Mogali (2014) studied the genetic variability in $284 F_{2}$ tomato plants derived from one cross, they found that both phenotypic and genotypic (PCV\& GCV) coefficient of variability were high for average fruit weight and total yield/plant, while they were low for plant height and days to first anthesis of $50 \%$ of plants. Genetic variability among 19 indeterminate tomato genotypes was studied by Meena 
et al. (2015), they found highly significant differences among all genotypes, and PCV was higher than GCV for all studied traits. The study of Lekshmi and Celine (2017) on forty tomato genotypes under greenhouse showed wide range of variability among the genotypes, indicating that selection for superior genotypes suitable for greenhouse conditions could be achieved. They also reported that GCVI PCV ratio was high for plant height, average fruit weight and yield/plant. It is necessary to know the extent and magnitude of additive and non additive gene effects, heritability and genetic gain of traits. The traits which have high values of GCV have high scope of improvement through selection (Patel et al., 2015; Lekshmi and Celine, 2017). High heritability accompanied with high genetic advance as percentage of mean were recorded for most studied traits in tomato, suggesting that these traits were controlled by additive gene effects and that the straight selection is very important and more effective in tomato improvement (Kumar et al., 2013; Sharanappa and Mogali, 2014; Rai et al., 2016; Singh et al., 2017).

In Egypt, few studies have been carried out for developing indeterminate tomato lines. Therefore, this study aimed to develop some indeterminate new lines by selection from two $F_{2}$ populations resulted from two commercial $F_{1}$ hybrids under El-Arish conditions, in addition to estimate the magnitude of variability, heritability and genetic advance.

\section{MATERIALS AND METHODS}

A field experimental work was carried out at the Experimental Farm, Faculty of Environmental Agricultural Sciences, Arish University, North Sinai, under greenhouse, during six successive seasons from 2012/2013 to 2017/2018 to develop some new indeterminate tomato lines for high vegetative growth vigour, high yield and fruit quality traits. The program was started with seeds of two $F_{2}$ populations which were obtained from two different commercial $F_{1}$ hybrids, i.e., "V59-48" with obovate fruits (Tezier Co.) and "Izmir" with globe fruits (Syngenta Co.).

In the first season (2012/2013), 1200 plants from each $F_{2}$ population were planted under two plastic greenhouses $(9 \mathrm{~m} \times 60 \mathrm{~m})$, and thirty five plants were selected from the 2400 plants and their seeds were separately collected to form $F_{3}$ populations. In $2^{\text {nd }}$ season (2013/2014), 65 plants from each of the 35 selected plants were grown as $F_{3}$ and the selection between and within $F_{3}$ populations was done for taller main stem, higher number of leaves, shorter time to achieve first flower as well as plants that produced higher early and total yield, selection also included fruit quality. Six populations were eliminated and seeds of the remained 29 families were separately collected as $F_{4}$ populations.

The selection was continued during the third season (2014/2015) to choose plants that had the desired characters to develop 29 families of $F_{5}$ populations concerning the mentioned traits. In the $4^{\text {th }}$ season (2015/2016), the 29 families of $F_{5}$ were grown to produce $F_{6}$ populations. In the $5^{\text {th }}$ season $(2016 / 2017)$, the 29 genotypes $\left(F_{6}\right)$ as well as, two check cultivars (CLN 1462A) brought from the Asian Vegetable Research and Development Center (AVRDC) and $F_{1}$ hybrid Myla from (Syngenta Co.) were used as control to determine the degree of homogeneity in the 29 families based on the estimated coefficient of variation (CV\%) for some traits i.e., plant height, number of leaves/plant, fruit length, fruit diameter and TSS\%. At the same season data were recorded, on yield and some fruit characteristics. Based on degree of homogeneity, nine families were excluded which showed high 
heterogeneity and the remaining 20 ones were evaluated under two plastic greenhouses in the six season (2017/2018) with the same check cultivars.

During all seasons seeds were sown in speedling trays at the second week of October and transplanted at the first week of December. In the latter two seasons, a randomized complete blocks design (RCBD) with three replications was used, each replicate contained 22 genotypes $\left(20 F_{6}\right.$ populations and 2 checks). The plot area was $13.5 \mathrm{~m}^{2}(9 \mathrm{~m}$ length $\times 1.5 \mathrm{~m}$ width). Drip irrigation system was used, each plot had two dripper lines and the distance between the double dripper lines centers was $\mathbf{1 5 0}$ $\mathrm{cm}$ and plants were set $50 \mathrm{~cm}$ apart. The chemical analysis of irrigation water over two seasons had EC $5.85 \mathrm{dSm}^{-1}$ and $\mathrm{pH}$ 7.17. The experimental soil was sandy loam while PH 8.06, EC $1.0 \mathrm{dSm}^{-1}$, organic matter $0.16 \%$ and $\mathrm{Ca}\left(\mathrm{Co}_{3}\right)_{2} \quad 22.53 \%$ (average of two seasons).The Irrigation and fertilization regimes, pest control as well as plant pruning were applied as commonly recommended in El-Arish Region.

Data recorded: Five plants from each plot were chosen and labled after 90 days from transplanting to determine plant height $(\mathrm{cm})$ and number of leaves/plant. All plants (36) /plot were harvested tell the end of the experiment and early yield /plant $(\mathrm{kg})$ which was yield of the first three harvesting, total yield/plant (kg) and average fruit weight (g) were then determined. Five fruits/plot were taken randomly in the third harvest for measuring, pericarp thickness ( $\mathrm{mm}$ ) and counting number of loculs/fruit. Fruit shape index was calculated by (fruit length $\mathrm{cm}$ (L)/fruit diameter $\mathrm{cm}$ (D)) and described according to UPOV Guide (2013). Total soluble solids percentage (TSS\%) was determined by a hand refractometer. Vitamin C content ( $\mathrm{mg} / 100$ g fresh weight) was determined by $\begin{array}{llll}\text { titration with } & 2, & 6\end{array}$ Dichlorophenolindophenol as described in A.O.A.C. (1990).

Statistical analysis: the combined data over the two seasons (2016/2017 and 2017/2018) were calculated and subjected to statistical analysis of variance according to Snedecor and Cochran (1980) and means separation was done according to Duncan (1955). Genotypic (GCV) and phenotypic coefficient of variation (PCV) were calculated according to Burton and Devane (1953). Heritability in broad sense was estimated according to Allard (1999). Genetic advance and genetic advance as percent of mean were calculated using the formula of Johnson et al. (1955).

\section{RESULTS AND DISCUSSION}

Degree of homogeneity was determined by estimated coefficient of variance (CV \%) as shown in Table (1). For plant height, it ranged from 3.86 to $17.39 \%$ for the selected genotypes. Twenty genotypes showed lower CV\% values than those of the check cultivars, indicating high homogeneity for this trait, while the remaining ones (9 genotypes) showed higher CV\% values than those of the check cvs. Regarding number of leaves/plant, most genotypes showed high homogeneity, since they gave the lowest CV\% values, they were close to those check cvs. in this respect. The genotypes VR-6, VL-3-4, VL-7-4, IRS-43-2 and IR-43-3 recorded the lowest CV\% values $(4.28,4.58,4.41,3.03$ and 4.92 , respectively), indicating that they were the most uniformity. Concerning days to first flower, most breeding lines showed low CV\% values compared with the check cultivars. Only seven lines were slightly higher than the control in this respect. 
Table 1: Estimation of coefficient of variance (CV\%) for six characters in the selected genotypes of tomato crop.

\begin{tabular}{|c|c|c|c|c|c|c|}
\hline Genotypes & $\begin{array}{l}\text { Plant } \\
\text { height }\end{array}$ & $\begin{array}{l}\text { Number of } \\
\text { leaves/plant }\end{array}$ & $\begin{array}{l}\text { Days to } \\
1^{\text {st }} \text { flower }\end{array}$ & $\begin{array}{c}\text { Fruit } \\
\text { length }\end{array}$ & $\begin{array}{c}\text { Fruit } \\
\text { diameter }\end{array}$ & TSS\% \\
\hline VR-1-2 & 7.95 & 10.19 & 11.14 & 10.56 & 9.27 & 10.94 \\
\hline VR-2-4 & 14.95 & 10.61 & 12.44 & 9.48 & 9.07 & 6.53 \\
\hline VR-3-1 & 9.59 & 10.14 & 8.59 & 12.84 & 11.91 & 7.71 \\
\hline VR-4-4 & 12.06 & 14.41 & 10.26 & 10.58 & 11.60 & 10.94 \\
\hline VR-4-3 & 7.39 & 5.04 & 3.28 & 5.06 & 6.69 & 2.94 \\
\hline VR-6 & 3.86 & 4.28 & 2.70 & 3.82 & 4.36 & 3.64 \\
\hline VR-6-40 & 4.89 & 5.12 & 4.45 & 3.36 & 5.96 & 2.59 \\
\hline VL-4-1 & 5.23 & 5.88 & 3.85 & 5.85 & 4.59 & 3.18 \\
\hline VL-4-4 & 5.71 & 5.35 & 4.97 & 4.51 & 6.01 & 4.51 \\
\hline VL-5-1 & 4.86 & 5.71 & 5.23 & 4.06 & 5.42 & 4.18 \\
\hline VL-5-4 & 5.27 & 5.52 & 3.57 & 5.07 & 4.87 & 3.23 \\
\hline VR-5-50 & 16.68 & 11.84 & 9.54 & 10.10 & 8.93 & 7.21 \\
\hline VR-7-1-1 & 15.45 & 12.39 & 10.86 & 9.69 & 8.32 & 7.84 \\
\hline VL-6-3 & 6.94 & 5.45 & 2.91 & 5.55 & 5.09 & 3.70 \\
\hline VL-6-4 & 17.39 & 12.89 & 10.14 & 10.08 & 12.83 & 10.07 \\
\hline VL-2-4 & 7.60 & 5.12 & 6.58 & 3.91 & 5.37 & 2.70 \\
\hline VR-2-5 & 5.52 & 6.52 & 3.95 & 4.27 & 4.35 & 3.11 \\
\hline VR-7-22 & 6.04 & 5.33 & 4.57 & 5.01 & 5.60 & 5.71 \\
\hline VL-2-3 & 4.64 & 6.71 & 3.55 & 3.79 & 4.17 & 3.17 \\
\hline VL-2-5 & 13.06 & 10.95 & 9.44 & 9.22 & 8.65 & 7.19 \\
\hline VL-3-4 & 4.04 & 4.58 & 4.38 & 4.44 & 3.20 & 5.47 \\
\hline VL-7-4 & 4.77 & 4.41 & 3.67 & 4.33 & 4.54 & 3.61 \\
\hline IR-43-1 & 6.15 & 5.51 & 2.07 & 4.88 & 4.29 & 2.32 \\
\hline IRS-43-2 & 4.30 & 3.03 & 2.20 & 3.14 & 3.35 & 2.54 \\
\hline IR-43-2 & 6.68 & 6.00 & 4.57 & 5.47 & 4.72 & 3.23 \\
\hline IR-43-3 & 4.34 & 4.92 & 2.25 & 4.64 & 3.08 & 4.47 \\
\hline IR-43-5 & 9.99 & 10.07 & 10.00 & 9.03 & 8.69 & 6.83 \\
\hline IR-44-1 & 5.61 & 5.12 & 4.45 & 3.91 & 4.42 & 2.49 \\
\hline IR-44-2 & 4.36 & 5.36 & 2.94 & 6.16 & 5.78 & 4.86 \\
\hline CLN1462A & 8.41 & 9.38 & 8.54 & 8.79 & 7.34 & 6.52 \\
\hline Myla F & 7.89 & 6.82 & 6.96 & 6.32 & 7.47 & 5.19 \\
\hline
\end{tabular}


Estimated coefficient of variances for both fruit length and diameter (Table 1) ranged from 3.14 to $12.84 \%$ and from 3.08 to $12.83 \%$, respectively. From the selected 29 genotypes, 20 ones were highly homogenous in both traits, since they showed low CV\% values, indicating that they were more homogenous among all genotypes. The genotypes VR-6, VR-640, VL-2-4, VL-2-3, IRS-43-2 and IR-44-1 recorded the lowest values for fruit length $(3.82,3.36,3.91,3.79,3.14$ and $3.91 \%$, respectively). While the breeding lines VL-3-4, IRS-43-2 and IR-43-3 showed the lowest values (3.20, 3.35 and 3.08) for fruit diameter.

Regarding total soluble solids (TSS\%), most selected lines showed high homogeneity, since they showed the lowest CV\% values.

In general, the estimated (CV\%) was varied among the genotypes in the same trait and from character to another in the same genotype. From the 29 selected genotypes, 20 ones were high homogenous in most traits under the conditions of this study compared with those of check genotypes. Therefore, these breeding lines could be considered as new homogenous lines for studying and evaluation. These results confirmed with those of Kansouh (2002) and Ahmed et al. (2017), who developed new local lines of tomato by selection from $F_{2}$ generations and the selected lines were enough homogenous for most traits since they exhibited low CV\% values.

\section{Mean performance of the new lines}

Analysis of variance (Table 2) showed highly significant differences among all studied genotypes in all traits, indicating that the developed lines exhibited adequate genetic variability and considerable scope for selection of the best materials for crop improvement. Similar results were previously reported by other workers (Rukhsar and Sharma, 2011; Sharanappa and Mogali, 2014; Taiana et al., 2015; Lekshmi and Celine, 2017). Data of mean performance for all studied traits are presented in Table (3). The plant height in the selected lines ranged from 186.01 in VR-6-40 to $270.0 \mathrm{~cm}$ in VL-5-4 lines with grand average of $221.17 \mathrm{~cm}$. Only six breeding lines significantly exceeded the highest check CLN1462A (230.0cm). However most obtained breeding lines showed plant height over $2.0 \mathrm{~m}$. Regarding number of leaves per plant, it was ranged from 22.5 to 34.7 for the lines IR-43.1 and VL-5-1, respectively. The Breeding lines VR-6, VL-4-1, VL-4-4, VL-5-1, VL-2-3, VL-7-4 and IR-44-2 produced the highest leaf number with insignificant differences among them and could be considered as high vigorous lines. Many researchers found significant differences among the tomato genotypes for plant height (Osekita and Ademiluyi, 2014; Reddy et al., 2014; Patel et al., 2015) and for number of leaves/plant (Kansouh, 2002; Meena et al., 2015). Days to first flower ranged from 31.0 to 45.0 with a mean of $\mathbf{3 6 . 8 8}$ day. Line IR-44-2 was the earliest in flowering (31.0 day) followed by both VL4-4 and VL-5-1(33.0 day). Most selected lines significantly decreased or were similar to the earliest check Myla $F_{1}(37.7)$.

Early yield for the selected lines ranged from 1.8 to $2.7 \mathrm{~kg} / \mathrm{plant}$ with an average of $2.23 \mathrm{~kg} / \mathrm{plant}$. Seven lines (VR6-40, VL-7-4, IRS-43-2, IR-43-2, IR-43-3, IR44-1 and IR-44-2) significantly exceeded the highest yielded check CLN1462A (2.4kg/plant), also the line IR-43-1 did not significantly differ from the same check in early yield. For total yield/plant, data in Table (3) revealed that five selected lines (VR-6, VR-6-40, IRS-43-2, IR-44-1 and IR44-2) significantly surpassed the best check CLN1462A (6.6kg/plant). The lowest yield $(4.2 \mathrm{~kg} / \mathrm{plant})$ was reflected by the line VL-6-3. However, all evaluated 
breeding lines, except 7 ones exceeded or equaled to the lowest yielded check (6.0kg/plant). So, it could be concluded that most developed lines had higher early and total yield compared with the check cvs and may be used in commercial production under greenhouse after further evaluation and as a source in breeding programs for improvement the fruit productivity in tomato. The results are confirmed by those of Kumar et al. (2013), Meena et al. (2015), Patel et al. (2015) and Ahmed et al. (2017), who found highly significant differences for early and total yield among the evaluated tomato lines.

Average means of some fruit characteristics are shown in Table (4). Average fruit weight ranged from 52.7 to $119.0 \mathrm{~g}$ with a mean of $85.48 \mathrm{~g}$. Among, 20 bred lines, three ones (IRS-43-2, IR-43-2 and IR-43-3) were significantly heavier fruits than the heaviest check cultivar (100.4g). While, the lightest fruits (52.7g) was recorded by the line VR-7-22. Rukhsar and Sharma (2011), Taiana et al., (2015) and Singh et al., (2017) found wide range of variability among evaluated tomato lines regarding average fruit weight. Concerning pericarp thickness, it ranged from 0.58 to $0.96 \mathrm{~cm}$ with a mean of $0.75 \mathrm{~cm}$. Four lines (VR-4-3, IR-43-1, IRS-43-2 and IR44-2) significantly exceeded the check CLN1462A in pericarp thickness $(0.73 \mathrm{~cm})$. However, ten lines were significantly similar to this check cultivar. Number of locules/fruit in the selected genotypes ranged from 2.03 to 4.00 with average of 2.73 . Two lines (IRS-43-2 and IR-43-2) had the larger number, while the lowest number was obtained by linesVL-3-4 and VL7-4. Moreover, six selected breeding lines (about $30 \%$ of all genotypes) did not significantly differ among them and from CLN1462A and Myla $F_{1}$ as check cvs in this respect. Some researchers confirmed these results such as Kumar et al. (2013) for pericarp thickness, Patel et al. (2015) for number of locules, Rai et al. (2016) and Singh et al. (2017) for pericarp thickness and number of locules.

Table 2: Analysis of variance for all studied traits of tomato crop.

\begin{tabular}{|l|c|c|c|}
\hline \multirow{2}{*}{\multicolumn{2}{|c|}{ Characters }} & \multicolumn{3}{c|}{ Mean sum of squares } \\
\cline { 2 - 4 } & $\begin{array}{c}\text { Replication } \\
\text { (d.f 2) }\end{array}$ & $\begin{array}{c}\text { Genotypes } \\
\text { (d.f 21) }\end{array}$ & $\begin{array}{c}\text { Error } \\
\text { (d.f 42) }\end{array}$ \\
\hline Plant height (cm) & $19.64^{\text {ns }}$ & $1875.64^{* *}$ & 26.03 \\
\hline No. leaves/plant & $1.28^{\text {ns }}$ & $53.55^{* *}$ & 3.55 \\
\hline Days to 1 ${ }^{\text {st }}$ flower & $3.29^{\text {ns }}$ & $33.32^{* *}$ & 1.03 \\
\hline Early yield/plant(kg) & $0.001^{\text {ns }}$ & $0.320^{* *}$ & 0.020 \\
\hline Total yield/plant(kg) & $0.043^{\text {ns }}$ & $1.867^{* *}$ & 0.034 \\
\hline Average fruit weight(g) & $22.094^{\text {ns }}$ & $950.655^{* *}$ & 48.254 \\
\hline Pericarp thickness(cm) & $0.004^{\text {ns }}$ & $0.030^{* *}$ & 0.001 \\
\hline No. locules/fruit & $0.002^{\text {ns }}$ & $1.106^{* *}$ & 0.004 \\
\hline Fruit shape index & $0.002^{\text {ns }}$ & $0.801^{* *}$ & 0.001 \\
\hline Vit.c content(mg/100g fresh weight) & $0.517^{\text {ns }}$ & $23.464^{* *}$ & 0.550 \\
\hline TSS percentage(\%) & $0.014^{\text {ns }}$ & $1.746^{* *}$ & 0.008 \\
\hline
\end{tabular}

ns, **: non significant and significant at the 0.01 levels of probability, respectively 
Table 3: Mean performance of the evaluated breeding lines of tomato for plant height, number of leaves/plant, days to first flower, early and total yield /plant.

\begin{tabular}{|c|c|c|c|c|c|}
\hline Lines & $\begin{array}{l}\text { Plant height } \\
\text { (cm.) }\end{array}$ & $\begin{array}{c}\text { No. leavesI } \\
\text { plant }\end{array}$ & $\begin{array}{l}\text { Days to } 1^{\text {st }} \\
\text { flower }\end{array}$ & $\begin{array}{c}\text { Early } \\
\text { yield/plant } \\
(\mathrm{kg})\end{array}$ & $\begin{array}{c}\text { Total } \\
\text { yield/plant } \\
\text { (kg) }\end{array}$ \\
\hline VR-4-3 & 199.3k & 25.3def & $39.3 c$ & $2.1 \mathrm{fgh}$ & $6.1 \mathrm{de}$ \\
\hline VR-6 & $210.7 j$ & $33.1 \mathrm{a}$ & $35.7 \mathrm{fgh}$ & 2.3def & $7.0 \mathrm{a}$ \\
\hline VR-6-40 & 186.01 & 24.1f & 37.0def & $2.6 a b c$ & $7.1 \mathrm{a}$ \\
\hline VL-4-1 & 249.7c & $33.7 a$ & $43.3 a$ & 1.9hi & $5.3 \mathrm{fg}$ \\
\hline VL-4-4 & $246.3 \mathrm{~cd}$ & $33.3 a$ & $33.0 \mathrm{i}$ & $1.9 \mathrm{ghi}$ & $6.0 \mathrm{de}$ \\
\hline VL-5-1 & $259.0 \mathrm{~b}$ & $34.7 a$ & $33.0 \mathrm{i}$ & 1.9hi & 5.0hi \\
\hline VL-5-4 & $270.0 a$ & $29.3 b c$ & 37.0def & 2.2ef & $5.4 f$ \\
\hline VL-6-3 & 240.0de & $29.7 \mathrm{bc}$ & $45.0 \mathrm{a}$ & $1.8 \mathrm{i}$ & $4.2 \mathrm{j}$ \\
\hline VL-2-4 & 213.1ij & 24.1f & $37.3 c-f$ & $1.8 \mathrm{i}$ & $5.1 \mathrm{gh}$ \\
\hline VR-2-5 & $231.4 \mathrm{ef}$ & $28.2 \mathrm{bcd}$ & $38.0 \mathrm{cde}$ & $1.8 \mathrm{i}$ & $5.6 f$ \\
\hline VR-7-22 & 209.7j & $27.8 \mathrm{cde}$ & 36.0e-h & $1.8 \mathrm{i}$ & $4.6 \mathrm{i}$ \\
\hline VL-2-3 & 247.1cd & $34.6 a$ & 34.3hi & 2.1efg & $5.9 \mathrm{e}$ \\
\hline VL-3-4 & 233.7ef & $29.8 b c$ & $37.7 \mathrm{c}-\mathrm{f}$ & 2.3def & $6.1 \mathrm{de}$ \\
\hline VL-7-4 & 231.9ef & $34.0 \mathrm{a}$ & 34.0hi & 2.6abc & $5.9 \mathrm{e}$ \\
\hline IR-43-1 & 187.01 & $22.5 f$ & $38.3 \mathrm{~cd}$ & 2.4cde & $6.3 \mathrm{~cd}$ \\
\hline IRS-43-2 & 208.5j & $27.8 \mathrm{cde}$ & 34.7ghi & $2.7 a b$ & $7.0 \mathrm{a}$ \\
\hline IR-43-2 & 186.31 & $23.3 f$ & 37.0def & $2.7 a$ & $6.1 \mathrm{de}$ \\
\hline IR-43-3 & $196.7 \mathrm{k}$ & 24.8def & 34.0hi & $2.7 a b$ & $6.2 \mathrm{de}$ \\
\hline IR-44-1 & $186.2 \mathrm{I}$ & 24.5ef & $36.7 \mathrm{~d}-\mathrm{g}$ & $2.5 \mathrm{abc}$ & $6.8 \mathrm{ab}$ \\
\hline IR-44-2 & 220.7hi & $34.2 a$ & $31.0 \mathrm{j}$ & $2.5 \mathrm{bcd}$ & $6.9 a b$ \\
\hline CLN1462A & $230.0 \mathrm{fg}$ & $31.6 a b$ & $41.3 b$ & 2.4cde & $6.6 \mathrm{bc}$ \\
\hline Myla $F_{1}$ & 222.4gh & 24.8def & $37.7 \mathrm{c}-\mathrm{f}$ & 2.2efg & $6.0 \mathrm{e}$ \\
\hline Mean & 221.17 & 28.87 & 36.88 & 2.23 & 5.96 \\
\hline
\end{tabular}


Table 4: Mean performance of the evaluated breeding lines of tomato for average fruit weight, pericarp thickness, number of locules/fruit, fruit shape index, Vit. $C$ and TSS\% contents.

\begin{tabular}{|c|c|c|c|c|c|c|}
\hline Lines & $\begin{array}{c}\text { Average } \\
\text { fruit } \\
\text { weight (g) }\end{array}$ & $\begin{array}{c}\text { Pericarp } \\
\text { thickness } \\
\text { (cm) }\end{array}$ & $\begin{array}{l}\text { No. } \\
\text { locules } \\
\text { Ifruit }\end{array}$ & $\begin{array}{l}\text { Fruit } \\
\text { shape } \\
\text { index }\end{array}$ & $\begin{array}{l}\text { Vit.C content } \\
\text { ( } \mathrm{mg} / 100 \mathrm{~g} \\
\text { fresh weight) }\end{array}$ & TSS (\%) \\
\hline VR-4-3 & $94.8 \mathrm{~cd}$ & $0.91 a$ & $3.10 \mathrm{~b}$ & $0.92 j$ & 26.7de & $6.60 \mathrm{ij}$ \\
\hline VR-6 & $92.9 \mathrm{~cd}$ & $0.67 d-g$ & $3.07 \mathrm{bc}$ & $1.23 \mathrm{i}$ & $29.7 \mathrm{bc}$ & $6.60 \mathrm{ij}$ \\
\hline VR-6-40 & 80.0 ef & $0.73 b-e$ & $3.05 \mathrm{bcd}$ & $1.20 \mathrm{i}$ & 24.0ghi & $5.80 \mathrm{~m}$ \\
\hline VL-4-1 & $68.9 f g$ & $0.58 \mathrm{~h}$ & $2.15 f$ & $1.80 \mathrm{e}$ & $25.2 \mathrm{fg}$ & $8.20 c$ \\
\hline VL-4-4 & $68.4 \mathrm{fg}$ & $0.66 \mathrm{~g}$ & $2.13 f$ & $1.73 f$ & 24.7fgh & $7.30 \mathrm{e}$ \\
\hline VL-5-1 & $71.2 \mathrm{fg}$ & $0.66 \mathrm{fg}$ & $2.07 f$ & $1.83 e$ & 21.9j & $6.80 \mathrm{~g}$ \\
\hline VL-5-4 & $69.9 \mathrm{fg}$ & $0.72 b-f$ & $2.97 \mathrm{~cd}$ & $1.90 \mathrm{~d}$ & $22.2 \mathrm{j}$ & $6.40 \mathrm{k}$ \\
\hline VL-6-3 & $65.5 \mathrm{~g}$ & $0.69 c-g$ & $2.07 f$ & $1.80 \mathrm{e}$ & 21.7j & $7.50 \mathrm{~d}$ \\
\hline VL-2-4 & $76.2 \mathrm{efg}$ & $0.69 \mathrm{c}-\mathrm{g}$ & $2.10 f$ & $1.40 \mathrm{~g}$ & 26.0ef & $6.60 \mathrm{ij}$ \\
\hline VR-2-5 & $63.9 \mathrm{gh}$ & $0.75 b$ & $3.08 b c$ & $1.30 \mathrm{~h}$ & 23.7hi & $8.33 b$ \\
\hline VR-7-22 & $52.7 \mathrm{~h}$ & $0.75 b$ & $2.96 \mathrm{~cd}$ & $1.30 \mathrm{~h}$ & $23.0 \mathrm{ij}$ & $8.27 b c$ \\
\hline VL-2-3 & 87.3de & $0.70 \mathrm{~b}-\mathrm{g}$ & $2.07 f$ & $1.97 \mathrm{c}$ & 30.3ab & $6.37 \mathrm{k}$ \\
\hline VL-3-4 & 85.8de & $0.73 \mathrm{bcd}$ & $2.03 f$ & $2.13 b$ & 24.7fgh & $6.43 \mathrm{jk}$ \\
\hline VL-7-4 & $93.8 \mathrm{~cd}$ & $0.74 \mathrm{bc}$ & $2.03 f$ & $2.50 a$ & 22.9ij & $8.53 a$ \\
\hline IR-43-1 & $94.9 \mathrm{~cd}$ & $0.96 a$ & $2.93 d$ & $0.83 \mathrm{kl}$ & $25.3 \mathrm{fg}$ & $7.07 f$ \\
\hline IRS-43-2 & $118.8 \mathrm{a}$ & $0.95 a$ & $4.00 a$ & 0.801 & $31.0 \mathrm{a}$ & 7.37de \\
\hline IR-43-2 & 108.3ab & $0.71 b-g$ & $4.00 a$ & 0.801 & $24.6 \mathrm{gh}$ & $6.33 \mathrm{k}$ \\
\hline IR-43-3 & $119.0 \mathrm{a}$ & $0.75 b c$ & $3.03 \mathrm{bcd}$ & $0.70 \mathrm{~m}$ & $25.0 \mathrm{fgh}$ & 6.63hi \\
\hline IR-44-1 & 80.0 ef & $0.73 \mathrm{bcd}$ & $3.00 \mathrm{bcd}$ & 0.87jk & $29.3 b c$ & $6.73 \mathrm{gh}$ \\
\hline IR-44-2 & $102.2 \mathrm{bc}$ & $0.92 a$ & $2.97 \mathrm{~cd}$ & $0.90 \mathrm{j}$ & 27.0de & $6.77 \mathrm{gh}$ \\
\hline CLN1462A & $100.4 \mathrm{bc}$ & 0.73b-e & $3.00 \mathrm{bcd}$ & 0.87jk & $29.0 c$ & $7.07 f$ \\
\hline Myla F 1 & 85.7de & 0.67 efg & $2.27 \mathrm{e}$ & $1.43 \mathrm{~g}$ & $27.3 d$ & 6.071 \\
\hline Mean & 85.48 & 0.75 & 2.73 & 1.37 & 25.68 & 6.98 \\
\hline
\end{tabular}

- Means followed by the same alphabetical letter (s) within each column are not significantly different at 5\% level according to Duncan's Multiple Range Test. 
Data of fruit shape index revealed that there were highly significant differences among the breeding lines in this respect. Three lines (VR-4-3, IR-44-1 and IR-44-2) produced globe fruits with shape index values of $0.92,0.87$ and 0.90 , respectively. While, the lines IR-6 and VR6-40 had oblong fruits (1.23 and 1.20, respectively). Six ones (VL-4-1, VL-4-4, VL-5-1, VL-5-4, VL-6-3 andVL-2-3) gave cylindrical fruits since the values of L/D were more than 1.5. Long- date shape was observed in both lines VL-3-4 (2.13) and VL-7-4(2.50). However, the lines IR43-1, IRS-43-2, IR-43-2, IR-43-3 gave oblate fruits, whereas L/D values ranged from 0.70 to 0.83 . The remaining lines, viz., VL-2-4, VR-2-5 and VR-7-22 produced obovate fruits with index values of 1.40 , 1.30 and 1.30 , respectively. It is obvious that the differences among selected lines for fruit shape index may be due to high genetic distance in this trait between the parents of the commercial hybrids (V5948 and Izmir).

For vitamin C content in fruits of recent breeding lines ranged from 21.7 to $31.0 \mathrm{mg} / 100 \mathrm{~g}$ fresh weight with average of 25.68mg. Four breeding lines (IRS-43-2, VL-2-3,VR-6 and IR-44-1) significantly exceeded CLN1462A line $(29.0 \mathrm{mg} / 100 \mathrm{~g})$. For total soluble solids (TSS\%), it exhibited that fruits of the linesVL-4-1, VL-2-5, VR-7-22 and VL-7-4 contained the highest values of TSS (more than $8.0 \%$ ) and significantly exceeded the remaining lines and check cvs. On the other hand, the line VR-6-40 recorded the lowest value $(5.80 \%)$. These results confirmed by Kansouh (2002), Rukhsar and Sharma (2011), Kumar et al. (2013) and Meena et al. (2015) who detected high genetic differences among genotypes in vitamin $\mathrm{C}$ and TSS\% contents in tomato fruits.

\section{Component of variances}

The estimated genetic parameters are shown in Table (5). The coefficient of variance (CV \%) was ranged from 1.25 to $8.13 \%$. The highest values were recorded in average fruit weight, number of leaves/plant and early yield/plant. While, the lowest values were given by total soluble solids $(1.25 \%)$, number of locules/fruit (2.25\%) and plant height (2.31\%).

The estimates of genotypic $\left(\sigma^{2} g\right)$ and phenotypic $\left(\sigma^{2} p\right)$ variances revealed that the genetic variances contributed with large portion of total variation in all studied traits, since the differences between $\sigma^{2} g$ and $\sigma^{2} p$ were small. These results are confirmed by those of Shashikanth et al. (2010), Mohamed et al. (2012) and Meena et al. (2015) for plant height, average fruit weight and TSS\%. Phenotypic (PCV \%) and genotypic (GCV $\%)$ coefficient of variations are very important in studying the extent and nature of genetic variability to design suitable breeding program for improving any character(s). PCV\% values were slightly higher than the GCV\% ones for all studied traits, indicating that the genetic variance plays the main role in expression of the character. This fact make the simple selection could be used for genetically improvement of crops. Similar conclusion were reported by many investigators among them Rukhsar and Sharma (2011), Kumar et al. (2013), Patel et al. (2015) and Singh et al. (2017).

Heritability estimates were high for all studied traits $(>75 \%)$, it ranged from $\mathbf{8 2 . 4 4}$ for days to $\mathbf{1}^{\text {st }}$ flower to $99.63 \%$ for fruit shape index, indicating minor environmental effects on the expression of these traits. Therefore, selection based on phenotypic observation as individual plant is effective for improvement these characters. This result is in agreement with those of Meena et al. (2015) for most growth and productivity, Patel et al. (2015) for plant height and total yield, Rai et al. (2016) for plant height, average fruit weight, total yield, pericarp thickness and 


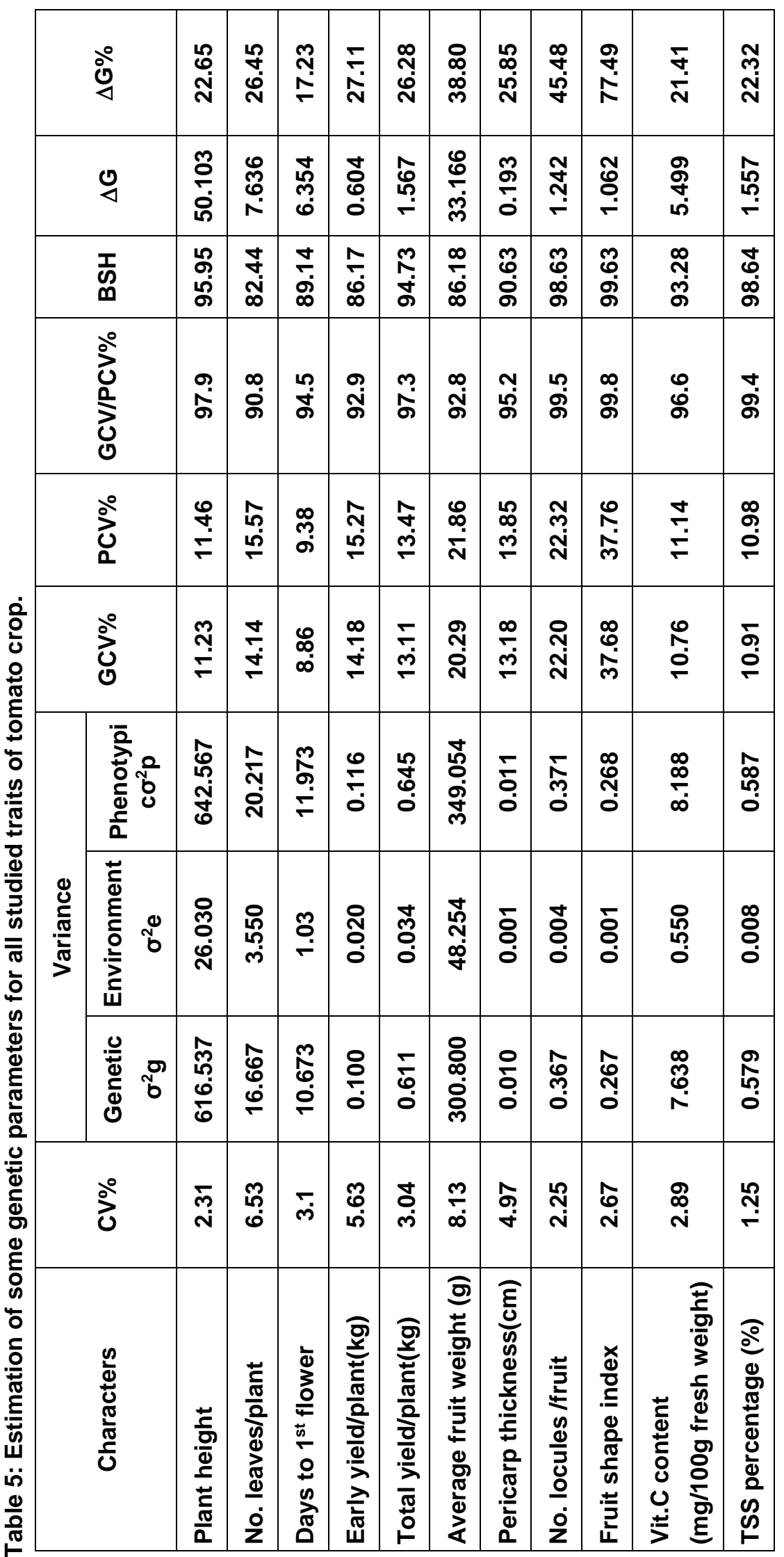


number of locules/fruit and Singh et al. (2017) for all traits.

The values of genetic advance $(\Delta G)$ ranged from 0.193 for pericarp thickness to $\mathbf{5 0 . 1 0 3}$ for plant height. However, genetic advance as percent of mean $(\Delta G \%)$ was high $(>20)$ for all traits. The high genetic advance help the plant breeder for predict genetic gain that obtained in the late generation of breeding program. High heritability linked with high genetic advance as percent is more useful than heritability alone for prediction of the results and effect of selection. In the present experiment, high heritability coupled with high genetic advance as percent were noted for all studied traits, indicating that the additive gene action played a predominant role in the inheritance of these characters and therefore, the selection is more effective for tomato improvement. Many workers reported that the most traits are controlled by the additive genes, among them Rukhsar and Sharma (2011) for Vit.C content and average fruit weight, Kumar et al. (2013) for total yield, Sharanappa and Mogali (2014) for average fruit weight, Reddy et al. (2014) for plant height, total yield and average fruit weight, Meena et al. (2015) for plant height, average fruit weight, total yield, TSS\% and Vit.C content and Rai et al. (2016) for plant height, total yield, average fruit weight, pericarp thickness and number of locules.

In conclusion, single selection is effective as a breeding method during $F_{2}$ and advanced generations for developing new superior indeterminate tomato lines. These new lines could be used for commercial production under greenhouses and as parents in breeding programs of tomato.

\section{REFERENCES}

Ahmed, M.F., H.A. Hamza, I. A. Ibrahim, A. A. Nower and M. Alansary (2017).
Developing new Egyptian local lines of tomato (Solanum lycopersicum L.). Menoufia J. Plant Prod., 2(2): 1- 10.

Allard, R.W. (1999). Principles of plant breeding. $2^{\text {nd }}$ ed. John Wiley and Sons.Inc., New York, U.S.A.

A.O.A.C. (1990). Official Methods of Analysis. Association of Official Analytical Chemists, Washington D.C. USA, $15^{\text {th }}$ ed. pp123-126.

Burton, G.W. and E.H. Devane (1953). Estimating heritability in tall fescue (Festuca arundinaceae) from replicated clonal material. Agronomy J., 45: 478-481.

Duncan, B.D. (1955). Multiple range and multiple $F$ test. Biometrics. 11: 142.

Johnson, H.W., H.F. Robinson and R.E. Comstock (1955). Estimates of genetic and environmental variability in soybean. Agronomy J., 47(7): 314-318.

Kansouh, A.M. (2002). Developing high yielding lines of tomato (Lycopersicon esculentum Mill) by selection. $2^{\text {nd }}$ Inter. Conf. Hort. Sci., 10-12 Sept. Kafr El- Sheikh, Tanta Univ., Egypt.

Kumar, S., P. Rattan and J.P. Sharma (2013). Genetic variation and character inter relationship studies for identification of selection parameters in tomato (Solanum lycopersicon L.). Indian J. Agric. Sci., 83 (11): 11491152.

Lekshmi, S.L. and V.A. Celine (2017). Genetic variability studies of tomato (Solanum lycopersicon L.) under protected conditions of Kerala. Asian J. Hort., 12(1): 106-110,

Meena, O.P., V. Bahadur, A.B. Jagtap, P. Saini and Y.K. Meena (2015). Genetic variability studies of fruit yield and its traits among indeterminate tomato genotypes under open field condition. African J. Agric. Res., 10(32): 31703177. 
Mohamed, S.M., E.E. Ali and T.Y. Mohamed (2012). Study of heritability and genetic variability among different plant and fruit characters of tomato (Solanum lycopersicon L.). Int. J. Sci. Tech. Res. 1:55-58.

Osekita, O.S. and A.T. Ademiluyi (2014). Genetic advance, heritability and character association of component of yield in some genotypes of tomato [Lycopersicon esculentum (Mill)]. Academia J. Biotechn., 2(1): 6-10.

Patel, M.S., N. Singh, A. Kumar, M.K. Singh, G.C. Yadav and M.B. Ghuge (2015). Genetic Variability, heritability and genetic advance of growth and yield componentsof tomato (Lycopersicon esculentum Mill). Environ. \&Ecol., 33 (3): 1034-1037.

Rai, A.K., A. Vikram and A. Pandav (2016). Genetic variability studies in tomato (Solanum lycopersicum L.) for yield and quality traits. Int. J. Agric., Environ. \&Biotech., 9(5): 739-744.

Reddy, R., B.H. Begum, A. Reddy, M. Sunil and M.P. Reddy (2014). Genetic variability and effect relationship for yield \& quantitative traits in exotic lines of tomato. Green Farming. 5 (1): 104-107.

Rukhsar, A.D. and J.P. Sharma (2011). Genetic variability studies of yield and quality traits in tomato (Solanum lycopersicum L.). Int. J. Plant Breed. Genet., 5(2): 168-174.

Sharanappa, K. P. and S.C. Mogali (2014). Studies on genetic variability, heritability and genetic advance for yield and yield components in F2 segregating population of tomato (Solanum lycopersicum L.). Karnataka J. Agric. Sci.,27 (4): 524-525.

Shashikanth, B.N., R.M. Hosamani and B.C. Patil (2010). Genetic variability in tomato (Solanum lycopersicum L.). Karnataka J. Agric. Sci., 23:536-537.

Singh, A.K., C.N. Ram, G.C. Yadav, R.K. Srivastava, C. Deo, D.K. Gautam, P. Kumar and P. Kumar (2017). Studies on genetic variability, heritability and genetic advance in tomato (Solanum lycopersicum L.) Int. J. Pure App. Biosci. 5(2):908-912.

Snedecor, G.W. and W.G. Cochran (1980). Statistical Methods; $7^{\text {th }}$ ed., lowa State Univ., Press. Ames. Iowa, USA.

Taiana, T., H. Ur-Rashid, S. Parveen, S. Hossain and A. Haque (2015). Selection strategies to choose better parents in tomato using genetic parameters.Plant Knowledge J., 4(1):33-39.

UPOV Guide (2013). International union for the protection of new varieties of plants.TG/44/11 Rev.pp1-72. 
تربيه سلالات جديدة من الطماطم الغير محدودة النمو بواسطة الانتخاب

\section{محمود إبراهيم محمود (') ، منى رشدى خليل(؟)}

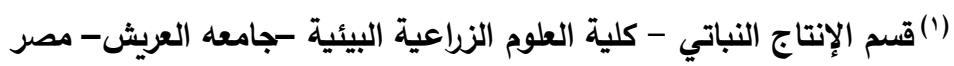

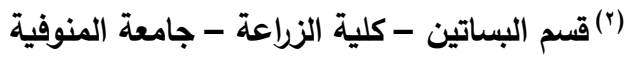

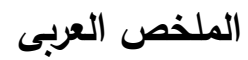

تم انتخاب عثرون سلاله جديدة من الطماطم الفير محدودة النمو بواسطة الإنتخاب داخل عثيرتين من الجيل الثاني

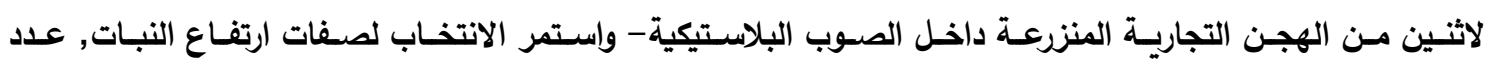

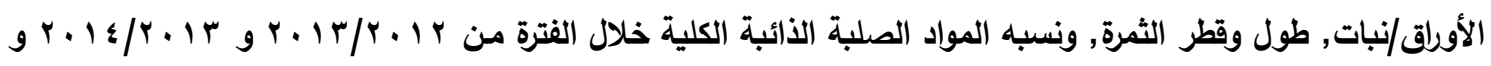

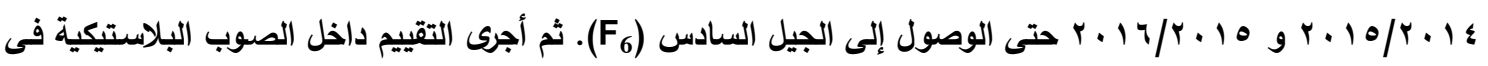

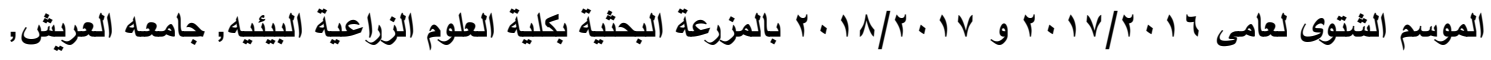

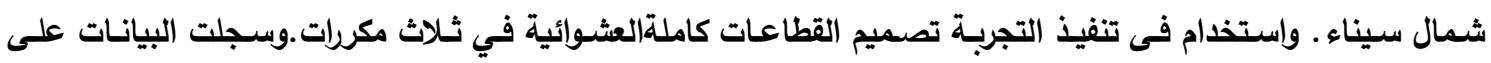

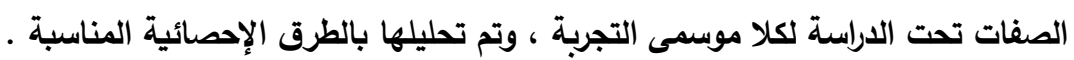

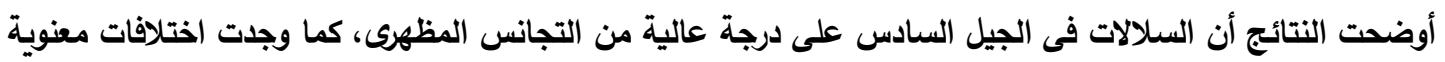

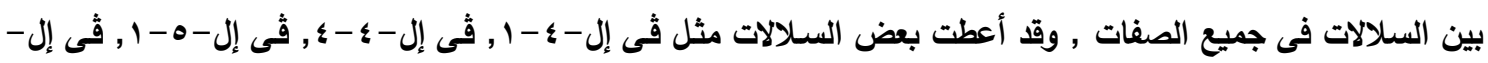

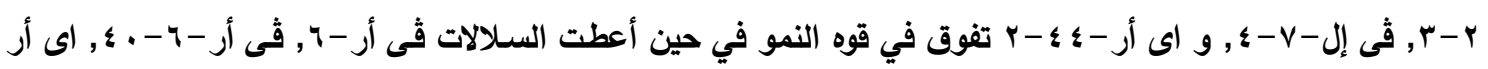

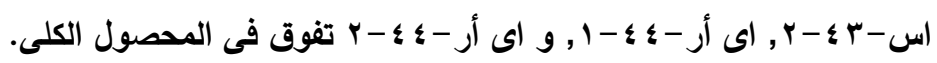

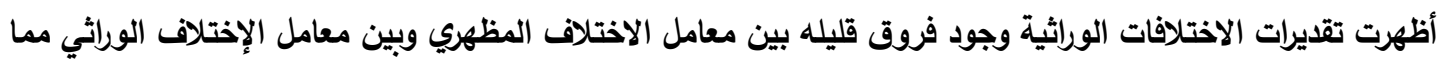

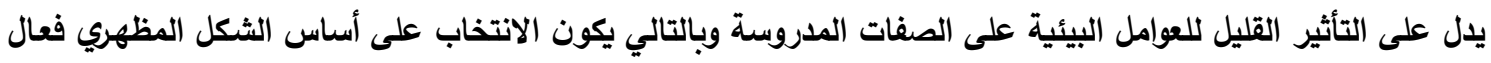

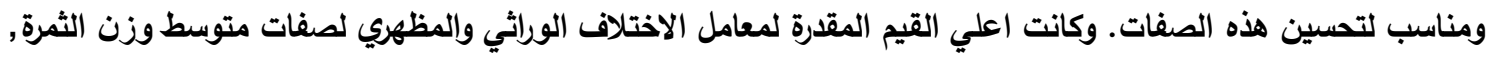

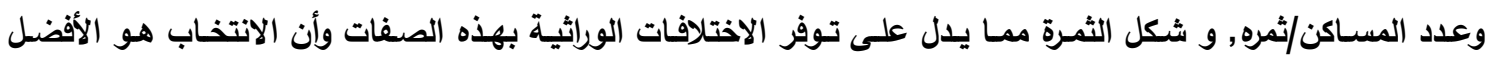

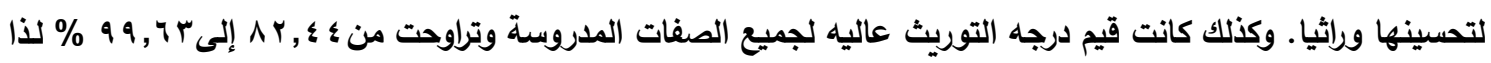

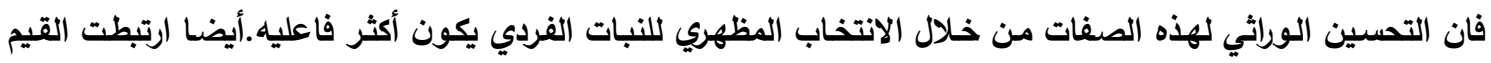

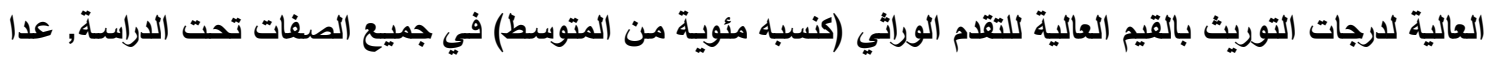

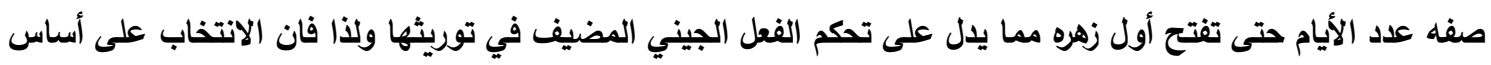
الأداء المظهري يكون مناسب وفعال للتحسين. 